\title{
Utilization of Construction Waste as Partial Replacement of Aggregates in Cement Concrete
}

\author{
Sandeep Kumar Chandel, Rajesh Goyal, Sandeep Singla
}

\begin{abstract}
This paper contains study of marble waste as replacement of fine and coarse aggregates in concrete. Entire planet is facing an issue of environment and climate. In this era sustainable development is in huge demand. Sustainable development has way of possibility by revising, rethinking, reducing, reusing. The use of construction waste materials in concrete industrial is playing key role to its economic, eco-friendly, green paybacks and engineering. This review reports on the utilization of waste marble as aggregate in concrete production industry. On the base of the reviewed studies, it was experiential that construction waste used in place of coarse aggregate contribute to the workability and mechanical properties of concrete. When natural aggregates relaced with coarse marble aggregates, ceramic tiles, recycled aggregates, it attained the best results at full replacement ratio. Additionally, waste construction materials in coarse aggregate form improves the mechanical properties over the dust form. These sustainable alternatives not only enhance mechanical properties of concrete but also boost economy.
\end{abstract}

Index Terms: Environment friendly, waste of Construction, waste from marble, tile waste, aggregates, sustainability, Aggregates, strength of concrete

\section{INTRODUCTION}

Over the world cement is the most generally utilized development material [6]. Since solid generation is at its top, because of this tremendous measure of cementitious material, normal totals (fine and course) including water are being utilized on the planet. In development industry cement is expending common assets in mass and in quick way. Because of utilization of these normal assets common parity of the planet is at high hazard. In this way, it is the main time to discover feasible choices of these issues. Then again, Construction industry is delivering enormous measure of this development squander worldwide in little, medium and huge undertakings. Asregular assets are at stack because of development, it is significant issue for specialists and because of this many research works are under advancement to discover suitable substitutions of common crude materials of cement. For the most part regular research fields for usage of waste materials are plastic waste, fly fiery remains, development squander [30]. These sorts of squanders are left into condition as obligation with zero beneficial return. Indeed, even alot of cashis being spent for its statement everywhere throughout the world and even land become futile in the majority of the cases. In current years,

Revised Manuscript Received on July 18, 2019.

Sandeep Kumar Chandel ,Civil Engineering, RIMT University, Mandi Gobindgarh Punjab , India.

Dr.Rajesh Goyal, Civil Engineering, NICMAR New Delhi, India.

Dr. Sandeep Singla, Civil Engineering, RIMT University, Mandi Gobindgarh Punjab , India. mechanical improvement of developing financial matters, for example, in Brazil, Russia, India, China and South Africa (BRICS) propose that the world interest for crude materials will further ascentinnot so distant future [13]. Additionally, modern advancements and human exercises ought to be anticipated at both expanding the effectiveness in (re-)utilizing crude materials and diminishing ozone depleting substance discharges. Truthbetold, the present rate of expending common assets will result in an unsustainable weight on the Earth's normal dependable qualities and assets [18] So, it is dependably a superior alternative to reuse this waste material in concrete as strengthening. The greater part of the development materials is having huge benefit of building properties. Expending these losses in cement a financially savvy move, yet additionally a stage towards condition well-disposed planet. When we centre around development squander wastage of floor items to be specific artistic tiles, marble chips are best elective items to reuse as totals in solid creation. This investigation focusses on gettingreadycementofproperquality with squashed waste clay tiles, marble chips, reused totals as course totals. Alongside mechanical properties water ingestion, crisp solid properties, Non-ruinous test likewise performed and assessed. Increasingly over altered cement gave manageable arrangement of customary cement, just as it gave conservative development too.

\section{A. Review Stage}

\begin{tabular}{|c|c|c|c|c|}
\hline Year & $\begin{array}{l}\text { Autho } \\
\mathrm{r}\end{array}$ & Material & Objective & Findings \\
\hline 2014 & $\operatorname{In}^{1}$ & Marble chips & $\begin{array}{l}\text { In this study } \\
\text { marble chips } \\
\text { wastereused as } \\
\text { course } \\
\text { aggregates. } \\
\text { Mechanical } \\
\text { properties } \\
\text { determined } \\
\text { for } \\
\text { different } \\
\text { replaced ratios } \\
\text { of samples. } \\
\text { Immersion } \\
\text { values of } \\
\text { samples also } \\
\text { determined. }\end{array}$ & $\begin{array}{l}\text { More } \\
\text { than } 28 \\
\text { days, the } \\
\text { compres } \\
\text { sive } \\
\text { quality } \\
\text { debilitat } \\
\text { ed at } \\
\text { substitut } \\
\text { ion } \\
\text { proporti } \\
\text { ons past } \\
\text { half, } \\
\text { while in } \\
\text { the } \\
\text { referenc } \\
\text { e test, } \\
\text { the } \\
\text { compress } \\
\text { ive } \\
\text { quality } \\
\text { improve }\end{array}$ \\
\hline
\end{tabular}




\begin{tabular}{|c|c|c|c|c|}
\hline & & & & $\begin{array}{l}\text { proporti } \\
\text { on. . Be } \\
\text { that as it } \\
\text { may, the } \\
\text { water } \\
\text { assimilat } \\
\text { ion } \\
\text { esteems } \\
\text { all } \\
\text { through } \\
\text { drenchin } \\
\mathrm{g} \text { and } \\
\text { carbonat } \\
\text { ion were } \\
\text { compara } \\
\text { ble in } \\
\text { the test } \\
\text { and } \\
\text { referenc } \\
\text { e tests. }\end{array}$ \\
\hline 2014 & $\operatorname{In}^{13}$ & $\begin{array}{l}\text { Construction } \\
\text { demolished } \\
\text { waste (CDW) }\end{array}$ & $\begin{array}{l}\text { This study } \\
\text { aimed on } \\
\text { reuse of } \\
\text { constructon } \\
\text { demolished } \\
\text { waste (CDW) } \\
\text { as alternative } \\
\text { of coarse } \\
\text { aggregates in } \\
\text { concrete } \\
\text { examination } \\
\text { continued } \\
\text { cleanedand } \\
\text { uncleaned } \\
\text { CDW material } \\
\text { to } \\
\text { Contemplte } \\
\text { its effect on } \\
\text { water } \\
\text { assimilatio } \\
\text { n and } \\
\text { hard } \\
\text { concrete }\end{array}$ & $\begin{array}{l}\text { Experim } \\
\text { ent } \\
\text { results } \\
\text { of this } \\
\text { paper } \\
\text { represent } \\
\text { physical } \\
\text { and } \\
\text { mechani } \\
\text { cal } \\
\text { properti } \\
\text { es of } \\
\text { RACs. } \\
\text { An } \\
\text { autogeno } \\
\text { us } \\
\text { cleaning } \\
\text { of } \\
\text { sample } \\
\text { gave } \\
\text { higher } \\
\text { and } \\
\text { positive } \\
\text { mechani } \\
\text { cal } \\
\text { results in } \\
\text { form of } \\
\text { uni-axial } \\
\text { compress } \\
\text { ive } \\
\text { strength. }\end{array}$ \\
\hline 2016 & $\operatorname{In}^{18}$ & $\begin{array}{l}\text { Ceramic tile } \\
\text { waste }\end{array}$ & $\begin{array}{l}\text { Objective of } \\
\text { this study } \\
\text { was to find } \\
\text { alternative } \\
\text { of coarse } \\
\text { aggregates } \\
\text { by using } \\
\text { ceramic tile } \\
\text { waste in } \\
\text { cement } \\
\text { concrete. } \\
\text { Study } \\
\text { focused } \\
\text { onmechanica } \\
1 \text { properties }\end{array}$ & $\begin{array}{l}\text { This } \\
\text { study } \\
\text { evaluate } \\
d \text { that } \\
100 \% \\
\text { replace } \\
\text { ment of } \\
\text { tile } \\
\text { waste } \\
\text { gave } \\
\text { better } \\
\text { mechani } \\
\text { cal } \\
\text { results } \\
\text { than }\end{array}$ \\
\hline
\end{tabular}




\begin{tabular}{|c|c|c|c|c|}
\hline & & & $\begin{array}{l}\text { \& lime } \\
\text { stone } \\
\text { cement. } \\
\text { Mechanialpr } \\
\text { opertiesexa } \\
\text { mined for } \\
\text { every } \\
\text { one of the } \\
\text { clusters }\end{array}$ & $\begin{array}{l}\text { vity, the } \\
\text { concrete } \\
\text { made } \\
\text { with } \\
\text { WTA } \\
\text { can be } \\
\text { used in } \\
\text { low } \\
\text { weight } \\
\text { areas. } \\
\text { Abrasio } \\
\text { n resistanc } \\
\text { e is } \\
\text { better in } \\
\text { modifie } \\
d \\
\text { concrete }\end{array}$ \\
\hline 2016 & $\operatorname{In}^{25}$ & Marble waste & $\begin{array}{l}\text { Marble } \\
\text { waste } \\
\text { reused to } \\
\text { find } \\
\text { sustainable } \\
\text { solution of } \\
\text { traditional } \\
\text { concrete } \\
\text { aggregates. } \\
\text { Mechanical } \\
\text { properties of } \\
\text { natural } \\
\text { course } \\
\text { aggregate } \\
\text { concrete } \\
\text { and } \\
\text { replaced } \\
\text { with } \\
\text { different ratios } \\
\text { carried out. }\end{array}$ & 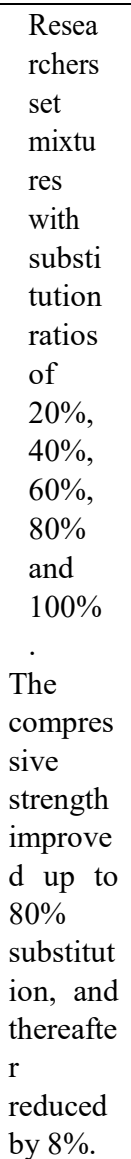 \\
\hline
\end{tabular}

In table no. 1 all analysts centered to discover option of conventional totals and reused distinctive development squanders. Be that as it may, every one of the examinations pursue the equivalent mechanical property test on various substitution proportions of cement. Water assimilation was additionally significant factor, which has been considered in every one of the papers. Alongside hard solid properties, crisp solid properties additionally considered and assessed. Indeed, even a portion of the analyst conveyed sifter investigations of materials.

\section{TESTING FOR COMPRESSIVE STRENGTH:}

Compressive strength was tested on concrete cubes of 150x150x150 mm size and to obtain 7days, 14 days and 28 days compressive strength using the compression testing machine. The max Value of the compressive strength at which specimen failed was noted. The average of three samples was taken as representative of compressive strength. Then the compressive strength was calculated by dividing the max. Compressive load by cross sectional area

$\mathrm{Fc}=$ Failure Load / cross sectional area

\section{RESULT}

TABLE 1 SHOWS THE RESULT OF COMPRESSIVE STRENGTH OF CUBES BY PARTIAL REPLACEMENT OF COARSE AGGREGATE BY CRUSHEDTILES:

\begin{tabular}{|l|l|l|l|}
\hline $\begin{array}{l}\text { Percentage } \\
\text { Replacement of } \\
\text { CA by crushed } \\
\text { Tiles }\end{array}$ & $\begin{array}{l}\text { 7days average } \\
\text { compressive } \\
\text { strength. } \\
(\mathrm{N} / \mathrm{mm} 2)\end{array}$ & $\begin{array}{l}\text { 14days } \\
\text { average } \\
\text { compressive } \\
\text { strength. } \\
(\mathrm{N} / \mathrm{mm} 2)\end{array}$ & $\begin{array}{l}\text { 28days } \\
\text { average } \\
\text { compressive } \\
\text { strength. } \\
(\mathrm{N} / \mathrm{mm} 2)\end{array}$ \\
\hline 0 & 24.42 & 25.8 & 36.90 \\
\hline 25 & 20.4 & 24.60 & 34.02 \\
\hline 50 & 20.16 & 24.90 & 31.1 \\
\hline 75 & 18.80 & 24.12 & 29.2 \\
\hline 100 & 16.4 & 23.18 & 27.2 \\
\hline
\end{tabular}

Table 2 show the result of compressive strength of cube by partial replacement by fine aggregate by marble dust

\begin{tabular}{|l|l|l|l|}
\hline $\begin{array}{l}\text { Percentage of } \\
\text { marble Dust in } \\
\text { replacement of } \\
\text { FA }\end{array}$ & $\begin{array}{l}7 \text { days avg } \\
\text { compressive } \\
\text { strength } \\
\text { (N/mm2) }\end{array}$ & $\begin{array}{l}\text { 14days avg. } \\
\text { compressive } \\
\text { strength }\end{array}$ & $\begin{array}{l}\text { 28days } \\
\text { average } \\
\text { compres } \\
\text { sive } \\
\text { strength }\end{array}$ \\
\hline $0 \%$ & 20.2 & 23.20 & 30.40 \\
\hline $25 \%$ & 21.28 & 25.20 & 32.10 \\
\hline $50 \%$ & 22.10 & 28.20 & 34.50 \\
\hline $100 \%$ & 14.70 & 18.20 & 21.10 \\
\hline
\end{tabular}

\section{CONCLUSION}

In this survey, the usage of waste marble, annihilated solid waste and earthenware tile squander in cement was watched. Concentrates on the substitution proportions of waste material were examined and their changes and similitudes were assessed. The goal was to perceive a typical substitution proportion and to give an unmistakable image of the specific investigations. The finishes of this total evaluation are outlined. 
In coarse total structure, all waste material substitution applies progressively idealistic impacts as the w/c proportion diminishes. The greater part of the cases have positive outcomes for assimilation properties and notwithstanding for crisp solid properties. Mechanical properties likewise improved because of altered cement

To improve the financial recuperation of squanders, it has been proposed supplanting an extent of cement with side-effects from the misuse of building destinations and plants. Studies have likewise analyzed the recuperation of unusable marble squanders, tile squander by granulating them into coarse totals that can be supplanted into cement. At the point when supplanted at reasonable proportions, marble, tiles apply no unfavorable impacts on solid quality yet may improve the mechanical properties. Giving by the evaluated investigations, the reuse of development squander in solid assembling benefits the economy and diminishes ecological contamination. Totals of marble squanders have all the earmarks of being particularly reasonable for solid creation in prepared blended solid plants. One thing that is normal in all papers, analysts featured the significance ofrestoring. Besides, it is additionally a significant factor to cleaning of reused totals and other waste materials, generally results are not ideal.

\section{REFERENCES}

[1] Andr_e,A., deBrito,J., Rosa, A.,Pedro, D., 2014. Durability performance of concrete incorporating coarse aggregates from marble industry waste. J. Clean. Prod. 65, 389e396.

[2] Andr_e, A.J.N.P., July 2012. Performance in Durability Terms of Concrete Incorporating Waste Coarse Aggregates from the Marble Industry. Instituto Superior Tecnico, Universidade Tecnica de Lisbona, Lisbon.

[3] Aruntas, H.Y., Gürü, M., Dayı, M., Tekin,_I., 2010. Utilization of waste marble dustas an additive in cement production. Mater. Des. 31 (8), $4039 \mathrm{e} 4042$.

[4] Binici,H., Shah, T., Aksoganc, O., Kaplan, H., 2008. Durability of concrete made with granite and marble as recycle aggregates. J. Mater. Proc. Technol. 208(1e3), 299e308.

[5] Corinaldesi, V., Moriconi, G., Naik, T.R., 2010. Characterization of marble powder for its use in mortar and concrete. Constr. Build. Mater. 24 (1), $113 \mathrm{e} 117$.

[6] Gameiro, F., deBrito, J., Correia da Silva, D., 2014. Durability performance structural concrete containing fine aggregates from waste generated by marble quarrying industry. Eng. Struct. 59,654e662.

[7] Gautam, N., Krishna, V., Srivastava, A., 2014. Sustainability in the concrete construction. Int. J. Environ. Res. Dev. ISSN: 2249-3131 4(1), 81e90.

[8] Elçi, H., Utilisation of crushed floor andwall tilewastes as aggregate in concrete production,Journal of Cleaner Production(2015), http://dx.doi.org/10.1016/j.jclepro.2015.07.003

[9] Hameed, M.S., Sekar, A.S.S., 2009. Properties of green concrete containing quarry rock dustandmarblesludgepowderasfineaggregate. ARPNJ.Eng. Appl.Sci.ISSN:1819- 66084 (4),83e89

[10] Hasan Sahan Arel "Recyclability of waste marble in concrete production" Journal of Cleaner Production 131 (2016) 179e188

[11] Hebhoub, H., Aoun, H., Belachia, M., Houari, H., Ghorbel, E., 2011. Use of waste marble aggregates in concrete. Constr. Build. Mater. 25 (3), $1167 \mathrm{e} 1171$.

[12] ShahidKabir,A.Al-Shayeb,ImranMKhan2016Recycledconstructiondebris as concrete aggregates for sustainable construction material, International conference on Sustainable Design, Engineering and Construction, Procedia Engineering 145 ( 2016 ) 1518-1525Published by Elsevier Ltd.

[13] Marco Pepe, Romildo D. Toledo Filho, Eduardus A.B. Koenders, Enzo M. (2014), Alternative processing procedures for recycled aggregates in structural concrete, Construction and Building Materials
69

(2014)

http://dx.doi.org/10.1016/j.conbuildmat.2014.06.084

[14] Monica, Ms, Dhoka, C., 2013. Green concrete: using industrial waste of marble powder, quarry dust and paper pulp. Int. J. Eng. Sci. Invent 2 (10), 67e70.ISSN(online):2319- 6734, ISSN (print):2319-6726

[15] Nagarajan, V.K., Devi, S.A., Manohari, S.P., Santha, M.M., 2014. Experimental study on partialreplacement ofcement with coconutshellash inconcrete.Int.J.Sci.Res.ISSN: 2278-3075 3 (3),651e661.

[16] Omar, O.M., Abd Elhameed, G.D., Sherif, M.A., Mohamadien, H.A., 2012. Influence of limestone waste as partial replacement material for sand and marble powder in concrete properties. HBRC J. 8 (3), $193 \mathrm{e} 203$.

[17] Pathan,V.G.,Pathan,G.,2014.Feasibilityandneedofuseofwastemarble powder in concreteproduction.IOSRJ.Mech.Civ.Eng.(IOSR-JMCE)23e26 e-ISSN:2278-1684,p- ISSN: 2320-334X.

[18] Paul O Awoyera, Julius M. Ndambauki, Joseph O Akinmusuru, David O. Omole, (2016)Characterization of ceramic waste aggregate Concret, HBRC Journal, http://dx.doi.org/10.1016/j.hbrcj.2016.11.003

[19] Rai, B., Khan, N.H., Abhishek, Kr, Tabin, R.S., Duggal, S.K., 2011 a. Influence of marble powder/granulesinconcretemix. Int. J. Civ. Struct. Eng. ISSN:0976-43991(4),827e834.

[20] Rai, B., Khan, N.H., Abhishek, Kr, Tabin, R.S., Duggal, S.K., 2011a. Influence of marble powder/granulesinconcretemix. Int. J. Civ. Struct. Eng. ISSN:0976-43991(4),827e834.

[21] Rai, B., Naushad, K.H., Abhishek, Kr, Rushad, S.T., Duggal, S.K., 2011. Influence of marble powder/granules in concrete mix. Int. J. Civ. Struct. Eng. 1 (4).

[22] Sadek, D.M., El-Attar, M.M., Ali, H.A., 2016. Reusing of marble and granite powders in self-compacting concretefor sustainable development.J.Clean.Prod.121,19e32

[23] Silva, R.V., de Brito, J., Dhir, R.K., 2014. Properties and composition of recycled aggregates from construction and demolition waste suitable forconcreteproduction.Constr. Build. Mater. 65, 201e21

[24] Sudarshan, D.K., Vyas, A.K., 2016. Impact of marble waste as coarse aggregate on properties of lean cement concrete. Case Stud. Constr. Mater

[25] Talah, A., Kharchi, F., Chaid, R., 2015. Influence of marble powder on high performance concrete behavior. Proced. Eng. 114, 685e690.

[26] Tennich, M., Kallel, A., Ouezdou, M.B., 2015. Incorporation of fillers from marble and tile wastes in the composition of self-compacting concretes. Constr.Build.Mater.91,65e70.

[27] Uyguno_glu, T., Topçu,_I.B., Çelik, A.G., 2014. Use of waste marble and recycled aggregates in self-compacting concrete for environmental sustainability. J.Clean. Prod.84, 691e700

[28] Sadek, D.M., El-Attar, M.M., Ali, H.A., 2016. Reusing of marble and granite powders in self-compacting concretefor sustainable development.J.Clean.Prod.121,19e32

[29] Silva, R.V., de Brito, J., Dhir, R.K., 2014. Properties and composition of recycled aggregates from construction and demolition waste suitable forconcreteproduction.Constr. Build. Mater. 65, 201e217

[30] Sudarshan, D.K., Vyas, A.K., 2016. Impact of marble waste as coarse aggregate on properties of lean cement concrete. Case Stud. Constr. Mater

[31] Talah, A., Kharchi, F., Chaid, R., 2015. Influence of marble powder on high performance concrete behavior. Proced. Eng. 114, 685e690. 


\section{AUTHORS PROFILE}

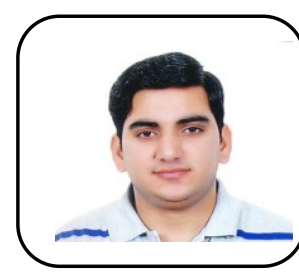

India.

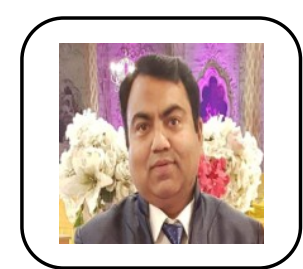

Dr.Rajesh Goyal received his Btech Dergree in civil engineering from NIT Kurukshetra ,Haryana.He recived his Phd from Indian Institute of Technology Roorkee(IIT Roorkee).He has Published Several Papers in National and International Journals.Presently working as Dean and Professor at NICMAR ,New Delhi.

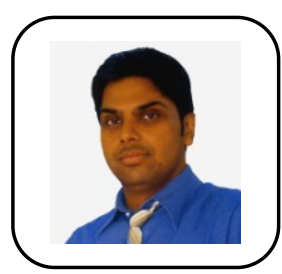

Dr. Sandeep Singla Received his Btech degree in civil engineering from Punjab technical university. Mtech from Thapar Institute of Engineering and technology Patiala \& Phd degree from National institute of Technology(NIT)

Kurukshetra. Presently he is working as Professor and head in department of civil engineering, RIMT University, Punjab, India. He has Published more than 60 Papers in national \& international journals/conferences.He has guided more than $30 \mathrm{M}$.Tech thesis. Besides being a member of board of studies in various universities, He is a life member of ISTE and also member of IEI. 